\title{
Yield, Yield Components and Grain Quality of Giza 179 Egyptian Rice Cultivar as Affected by Seeding Rates and Nitrogen Levels using Broadcasting Planting Method
}

\author{
Medhat A.E. El-Dalil1 ${ }^{1}$, Eman K.E. Abd-El Ghany ${ }^{1,}$ Abu El-Ezz, A.Fouad ${ }^{2}$
}

\begin{abstract}
The present study was conducted to evaluate the yield and grain quality of Giza179 rice cultivar as affected by seeding rates $(20,30,40$ and $50 \mathrm{Kg} / \mathrm{fed})$ and nitrogen fertilization levels $(0,20,40$ and $60 \mathrm{Kg} \mathrm{N} / \mathrm{fed})$ with broadcasting planting method. Two field experiments were carried out at the Experimental Farm of Etai El- Baroud Agricultural Research Station, Behaira Governorate, Agriculture Research Center (ARC) in 2014 and 2015 seasons. The results revealed that seeding rate of $40 \mathrm{~kg} / \mathrm{fed}$ gave a significantly higher paddy yield of (3.77 -3.79 ton/fed) in both seasons. Nitrogen application at $40 \mathrm{Kg}$ $\mathrm{N} /$ fed provided a maximum paddy yield $(4.25$ and 4.10 ton/fed) in both seasons. The yield and all yield components were significantly affected by seeding rates and nitrogen levels in the two seasons. Regarding quality, the amylose, protein content, elongation, hardness, gel consistency (GC), gelatinization temperature (GT), the rice kernel characteristics, hulling, milling and broken rice were affected by seeding rates and nitrogen levels with insignificant interaction. From the results, it is concluded that using broadcasting planting method for Giza179 Egyptian rice cultivar, higher paddy rice yield, yield components and good quality can be obtained at $40 \mathrm{Kg} / \mathrm{fed}$ seeding rate with $40 \mathrm{~kg} \mathrm{~N} / \mathrm{fed}$.
\end{abstract}

Key words: Seeding rates, nitrogen application levels, broadcasting method, yield, quality, amylose content, Oryza sativa, L.

\section{INTRODUCTION}

Rice (Oryza sativa L.) is the most important and widely cultivated crop in the world. It is grown in more than 100 countries, predominantly in Asia (Depar et al., 2011) and provides $21 \%$ and $15 \%$ per capita of dietary energy and protein, respectively. Rice crop is grown by many ways depending upon resource availability. Due to resource constraints, especially water and labours, direct seeding under dry condition is now emerging as a new trend in rice cultivation.

Rice occupies a unique position in many countries because for its importance in traditional diets and the main source of income of many peoples in the world. It is considered the most popular and important field crop in Egypt for several reasons as a staple food after wheat, as an exporting crop, as a land reclamation crop for improving the productivity of the saline soils widely spread in northern part of the delta and coastal area, and finally it is a social crop, where every person in the farmers family could find work in rice fields and earn money during the growing season. Rice crop plays a significant role. In Egypt, rice crop is considered a strategic crop for sustaining the food self-sufficiency (Anis et al. 2016).

Badr et. al. (2007) reported that the maximum seed productivity was obtained by using manual transplanting and big combine and the minimum yield was obtained by using seed drill and manual harvesting.

Nowadays, rice cultivation is done in different ways in the world. The most important cultivation ways are direct seeded and transplanting methods. Direct seeding of rice (DSR) refers to the process of establishing a rice crop from seeds sown in the field rather than by transplanting rice (TPR) seedling from the nursery. There are three principal methods of DSR: dry seeding (sowing dry seeds into dry soil), wet seeding (sowing pre-germinated seeds on wet puddle soils) and water seeding (seeds sown into standing water) ( Hassan and Kaviani, 2011). In Asia, conventional TPR has been replaced by dry seed broadcasting (DSR), mainly because of the higher cost of TPR and a shortage of the labor required (Dawe, 2005; Pandey et al., 2002; Tuong et al., 2005).Finally the rice cultivation system in the world is affected by water deficient, low suitable land, and shortages of worker (Nguyen and Ferrero, 2006). At present, $23 \%$ of rice is direct-seeded globally (Rao et al., 2007). In addition to higher economic returns, DSR crops are faster and easier to plant, less labor intensive and consume less water (Jehangir et al., 2005; Balasubramanian and Hill, 2002).

Direct seeding is practiced where water supply control is good. Advantages of direct seeding over transplanting include good stand establishment, higher tillering, and sometimes higher grain yield. Other advantages are stable growth and reduced lodging, better pest control, less risk due to drought and flooding damage, and low requirements for better water

${ }^{1}$ Rice Research Technology Center, Field Crops Research Institute,

Agricultural Research Center, Alexandria, Egypt.

${ }^{2}$ Rice Research and Training Center, Field Crops Research Institute,

Agricultural Research Center, Sakha-Kafr El- Sheikh, Egypt.

Received October 22,2017, Accepted November 07, 2017 
management practices Farooq et al. (2007). In contrary, transplanting is more laborious, time-consuming, and expensive than direct seeding. This is because of difficulties in raising seedlings, high cost of labor, and labor shortage (Pandey et al. 2002).

Nitrogen plays a vital role in determining the growth and yield potential of crops. According to Ananthi et al. (2010), the best rate of mineral fertilizer is that which produces maximum economic return at minimum cost. Nitrogen is one of the most essential macronutrients for rice production and usually, it is one of the most yield limiting in irrigated regions of rice production all over the world (Samonte et al. 2006).

The nitrogen deficiency in the Egyptian soils is one of major limiting factor for rice production, as nitrogen is an essential element to the rice plant, with about $75 \%$ of leaf $\mathrm{N}$ associated with chloroplasts, which are physiologically important in dry matter production through photosynthesis (Abdel Fattah et al 2013).

Modern rice cultivars are always responsive to balanced application of fertilizer. Proper management of nitrogen is necessary to improve crop growth and grain yield (Alam et al., 2011). Compared with other mineral nutrients, the optimal rate of nitrogenous fertilizer application is vital to decrease the environmental impact of excessive nitrogen and to increase profitability in crop production (Bilbao et al. 2004). In most cases, farmers use imbalanced dose of nitrogenous fertilizer which results in higher incidence of attacks by insects or pests, thereby lowering the yield of rice (Alam et al. 2011).

At present, the world is facing the problem of shortage of major fertilizer nutrients especially Nitrogen and Phosphorous. The developing countries like Egypt are more sensitive to this shortage because the fertilizer production in these countries is expensive and less than its demand. Even when the fertilizer supply is satisfactory, the importance of increasing its efficient use cannot be underestimated. The application of nitrogen fertilizer either in excess or less than optimum rate affects both yield and quality of rice to remarkable extent, hence proper management of crop nutrition is of immense importance.

Nitrogen absorbed by rice during the vegetative growth stages contributed in growth during reproduction and grain-filling through translocation (Bufogle et al., 1997; Norman et al., 1992). Nitrogen is very essential for the growth and development of crops. It enhances biomass and seed yield subject to the efficient water supply. Lack of $\mathrm{N}$ results stunted growth, pale yellow color, small grain size and poor vegetative as well as reproductive performance. Nitrogen is an essential component of amino acid and related protein of the plant structure. Growth of plants primarily depends on nitrogen availability in soil solution and its utilization by crop plants during growth and development (Awan et al. 2011).

Quality of the produce is much important as quantity in all walks of life and particularly in directly consuming commodities. Present investigation was planned to determine the effect of seeding rates combined with different nitrogen levels on the yield, yield components and grain quality of Giza 179 Egyptian rice cultivar using broadcasting planting method.

\section{MATERIALS AND METHODS}

Two field experiments were conducted at the Experimental Farm of Etai El- Baroud Agricultural Research Station, Behaira Governorate, Agriculture Research Center (ARC), during 2014 and 2015 seasons to evaluate the performance of Giza 179 rice cultivar under different seeding rates and nitrogen levels. The experiment was laid out in split plot arrangements under the Randomized Complete Block design using three replications, with seeding rates as the main plots and nitrogen levels as the sub plots.

Four different seeding rates were used for planting with broadcasting method, i.e. $(20,30,40$, and 50 $\mathrm{Kg} / \mathrm{fed}$ ).

Nitrogen fertilizer was applied in the urea form $(46.5 \% \mathrm{~N})$ in two splits $(2 / 3$ was applied and mixed in the dry soil before flooding. The remaining $1 / 3$ was added at panicle initiation stage) with different levels, i.e. $(0,20,40$ and $60 \mathrm{Kg} \mathrm{N} / \mathrm{fed})$.

Soil samples were taken from experimental site at depth of $0-30 \mathrm{~cm}$ from soil surface. Soil analysis was conducted according to the methods of Black et al. (1965). Results of soil analysis were shown in Table (1) for both seasons.

Table 1. physical and chemical analysis of the soil at the experimental site during 2014 and 2015 seasons

\begin{tabular}{lcc}
\hline Soil properties & $\mathbf{2 0 1 4}$ & $\mathbf{2 0 1 5}$ \\
\hline Sand \% & 11.8 & 12.5 \\
Silt \% & 20.6 & 22.4 \\
clay \% & 67.6 & 65.1 \\
Soil texture & Clay & Clay \\
Organic matter \% & 1.3 & 1.8 \\
pH & 7.5 & 7.9 \\
EC & 1.3 & 1.7 \\
Total N \% & 0.23 & 0.30 \\
Available P ppm & 16.2 & 19.1 \\
Available K ppm & 621 & 645 \\
Available Zn ppm & 0.85 & 1.12 \\
Total soluble salts (mg/L) & 10.21 & 9.45 \\
\hline
\end{tabular}


Grain yield was measured from an area of $12 \mathrm{~m}^{2}$ (3x4 m) which was harvested from each plot at random; avoiding the border effects. Grain yield was adjusted to $14 \%$ moisture content determined according to Yoshida(1981).Ten panicles were randomly collected from each plot to determine 1000-grain weight and number of filled grains/ panicle.

Furthermore, grain quality characters were recorded according to International Rice Research Institute (IRRI 1996).

Data collected were subjected to statistical analysis of variance according to Gomez and Gomez (1984) using SAS program, version 8.0.

\section{RERSULTS AND DISCUSSION}

Data in table (2) revealed that number of filled grains/ panicle, number of panicles $/ \mathrm{m}^{2}, 1000$ grain weight and grain yield were significantly affected by using different seeding rates during both seasons. The paddy yield was significantly affected by increase seeding rate up to $40 \mathrm{Kg}$ S/fed and gave the highest yield ( 3.77 and 3.79t/fed) in 2014 and 2015 seasons respectively, while the lowest values obtained at $20 \mathrm{Kg}$ Seeds/fed (3.58 and $3.30 \mathrm{t} / \mathrm{fed})$ in 2014 and 2015 seasons, respectively. These results were in harmony with Ali Abou Khalifa et al. (2014). Generally, increasing nitrogen rates significantly enhanced the paddy yield over the control in both seasons, and the best results obtained from using $40 \mathrm{~kg} \mathrm{~N} / \mathrm{fed}$ that recorded the highest yield (4.25 and $4.10 \mathrm{t} / \mathrm{fed})$ in 2014 and 2015 seasons, respectively. Similar results were obtained by Sultan et al. (2014).

Data indicated that number of filled grains/ panicle was affected significantly with different seeding rates. Table 2. Grain Yield and its com
during 2014 and 2015 seasons

\begin{tabular}{|c|c|c|c|c|c|c|c|c|}
\hline \multirow{2}{*}{$\begin{array}{l}\text { Main effects \& } \\
\text { interaction }\end{array}$} & \multicolumn{2}{|c|}{$\begin{array}{l}\text { Number of filled } \\
\text { grains/panicle }\end{array}$} & \multicolumn{2}{|c|}{$\begin{array}{l}\text { Number of } \\
\text { panicles } / \mathbf{m}^{2}\end{array}$} & \multicolumn{2}{|c|}{$\begin{array}{c}1000 \text { grain weight } \\
\text { (gm) }\end{array}$} & \multicolumn{2}{|c|}{$\begin{array}{c}\text { Grain yield } \\
\text { (ton/fed) }\end{array}$} \\
\hline & 2014 & 2015 & 2014 & 2015 & 2014 & 2015 & 2014 & 2015 \\
\hline \multicolumn{9}{|l|}{ Seeding rate $(S)$ : } \\
\hline $20 \mathrm{Kg} / \mathrm{fed}$ & 76.67 & 74.58 & 319.8 & 318.1 & 23.02 & 22.65 & 3.58 & 3.30 \\
\hline $30 \mathrm{Kg} / \mathrm{fed}$ & 80.08 & 78.92 & 343.7 & 340.6 & 23.05 & 22.86 & 3.70 & 3.44 \\
\hline $40 \mathrm{Kg} / \mathrm{fed}$ & 93.00 & 91.08 & 370.2 & 370.5 & 23.87 & 23.61 & 3.77 & 3.79 \\
\hline $50 \mathrm{Kg} / \mathrm{fed}$ & 85.58 & 85.33 & 365.4 & 364.4 & 23.52 & 23.53 & 3.75 & 3.76 \\
\hline L.S.D $D_{0.05}$ & 3.071 & 0.104 & 3.578 & 5.468 & 0.175 & 0.422 & 0.127 & 0.137 \\
\hline \multicolumn{9}{|l|}{ Nitrogen levels $(\mathrm{N})$ : } \\
\hline Control & 71.33 & 70.25 & 334.5 & 330.1 & 19.72 & 19.57 & 2.40 & 2.41 \\
\hline $20 \mathrm{Kg} \mathrm{N} / \mathrm{fed}$ & 82.08 & 81.00 & 346.0 & 343.7 & 24.28 & 24.03 & 4.05 & 3.78 \\
\hline $40 \mathrm{Kg} \mathrm{N} / \mathrm{fed}$ & 93.58 & 92.08 & 364.3 & 365.5 & 25.11 & 24.83 & 4.25 & 4.10 \\
\hline $60 \mathrm{Kg} \mathrm{N} / \mathrm{fed}$ & 88.33 & 86.58 & 354.3 & 354.2 & 24.35 & 24.22 & 4.05 & 3.99 \\
\hline L.S.D $D_{0.05}$ & 2.02 & 2.13 & 3.34 & 4.09 & 0.31 & 0.24 & 0.09 & 0.05 \\
\hline \multicolumn{9}{|l|}{ Interaction: } \\
\hline$S \times N$ & $* *$ & $* *$ & $* *$ & $* *$ & $* *$ & $* *$ & $* *$ & $* *$ \\
\hline
\end{tabular}

The highest values (93.00 and 91.08) produced at $50 \mathrm{Kg}$ seeds/fed in 2014 and 2015 sesons. In the reverse trend, the lowest values (76.67 and 74.58) resulted from 20 $\mathrm{Kg}$ seeds /fed in the first and second seasons, respectively. These results are in agreement with those reported by Abou Khalifa et al. (2005), and El-Khoby (2004).

Number of filled grains/ panicle was affected significantly with different nitrogen levels. Nitrogen fertilizer application at $40 \mathrm{Kg} / \mathrm{fed}$ recorded the highest number of filled grains /panicle (93.58 and 92.08) in 2014 and 2015 seasons. Conversely the lowest values of filled grains /panicle (71.33 and 70.25) resulted from control treatment in the two successive seasons. Similar findings have been reported by Bhowmick and Nayak (2000), Nawaz (2002), Namba (2005). Increasing number of grains per panicle that obtained in treatments receiving higher nitrogen rates were probably due to better nitrogen status of plant during panicle growth period.

The highest number of panicles $/ \mathrm{m}^{2}$ (370.2 and $370.5)$ were recorded with seeding rate of $50 \mathrm{Kg}$ seeds/fed in 2014 and 2015 seasons, respectively. In the reverse trend, the lowest values (319.8 and 318.1) were recorded with seeding rate $20 \mathrm{Kg} \mathrm{S} /$ fed in the first and second seasons, respectively Table (2). These results are in a good harmony with those reported by Sharief et al. (2000) and Abou Khalifa et al. (2005).

Data presented in Table (2) showed that the variation in nitrogen fertilization levels induced highly significant differences in number of panicles $/ \mathrm{m}^{2}$ in both seasons. The highest number of panicles $/ \mathrm{m}^{2}$ (364.3 and $365.5)$ were recorded with the treatment of $40 \mathrm{~kg} \mathrm{~N} / \mathrm{fed}$, in the first and second seasons, respectively, 
while lowest numbers of panicles(334.5 and 330.1) were found in the non-fertilized plots in the two successive seasons. Similar results were obtained by ElKassaby et al. (2012).

The 1000-grain weight was affected significantly with different seeding rates. The highest values were obtained (23.87 and $23.61 \mathrm{~g})$ with seeding rate at 50 $\mathrm{Kg} / \mathrm{fed}$ in 2014 and 2015 seasons, respectively, however, the lowest values were obtained (23.02 and $22.65 \mathrm{~g}$ ) with seeding rate $20 \mathrm{Kg} / \mathrm{fed}$ in the first and second seasons, respectively. Similar results were obtained by Sharief et al. (2000) and Abou Khalifa et al. (2005)

The 1000-grain weight was affected significantly with different nitrogen levels. .Nitrogen application at $40 \mathrm{Kg} /$ fed recorded the highest values $(25.11 \mathrm{~g}$ and $24.83 \mathrm{~g}$ ) in 2014 and 2015 seasons, however, the lowest values (19.72 and $19.57 \mathrm{~g})$ were produced by control treatment in both seasons, respectively. Similar finding have been reported by Bhowmick and Nayak (2000),

Gorgy (2007),Awan et al. (2011), and Yousef et al. (2012),

Increase the grain weight at higher nitrogen rates might be primarily due to increase in chlorophyll content of leaves which led to higher photosynthetic rate and ultimately plenty of photosynthesis available during grain development.

Data in Table (3) showed that seeding rate $x$ nitrogen level interactions had highly significant effects Table 3. The interaction between seeding rates and nitrogen levels effect on yield and yield components characters during 2014 and 2015 seasons

\begin{tabular}{|c|c|c|c|c|c|c|c|c|c|}
\hline \multirow{2}{*}{$\begin{array}{c}\text { Seeding rate } \\
(\mathrm{Kg})\end{array}$} & \multirow{2}{*}{$\begin{array}{c}\text { Nitrogen levels } \\
\text { (Kg N/fed) }\end{array}$} & \multicolumn{2}{|c|}{$\begin{array}{c}\text { Number of filled } \\
\text { grains/panicle }\end{array}$} & \multicolumn{2}{|c|}{$\begin{array}{l}\text { Number of } \\
\text { panicles } / \mathbf{m}^{2}\end{array}$} & \multicolumn{2}{|c|}{$\begin{array}{c}1000 \text { grain weight } \\
(\mathrm{gm})\end{array}$} & \multicolumn{2}{|c|}{ Grain yield (t/fed) } \\
\hline & & 2014 & 2015 & 2014 & 2015 & 2014 & 2015 & 2014 & 2015 \\
\hline \multirow{4}{*}{20} & Control & 65.33 & 61.33 & 309.33 & 304.33 & 18.73 & 18.60 & 2.13 & 1.90 \\
\hline & 20 & 79.00 & 78.00 & 319.33 & 318.67 & 24.26 & 23.56 & 3.98 & 3.65 \\
\hline & 40 & 80.00 & 79.00 & 325.33 & 328.33 & 25.20 & 24.73 & 4.18 & 3.88 \\
\hline & 60 & 82.33 & 80.00 & 325.00 & 321.00 & 24.03 & 23.70 & 4.03 & 3.77 \\
\hline \multirow{4}{*}{30} & Control & 71.00 & 73.00 & 331.67 & 327.00 & 18.50 & 18.30 & 2.60 & 2.46 \\
\hline & 20 & 81.00 & 80.33 & 344.33 & 342.67 & 24.33 & 24.16 & 3.88 & 3.67 \\
\hline & 40 & 84.33 & 81.33 & 349.67 & 343.00 & 24.96 & 24.73 & 4.20 & 3.81 \\
\hline & 60 & 84.00 & 81.00 & 349.33 & 347.00 & 24.30 & 24.26 & 4.11 & 3.79 \\
\hline \multirow{4}{*}{40} & Control & 74.67 & 75.33 & 346.00 & 341.33 & 20.83 & 20.80 & 2.33 & 2.56 \\
\hline & 20 & 86.00 & 82.67 & 361.00 & 359.33 & 24.86 & 24.20 & 4.20 & 3.80 \\
\hline & 40 & 114.67 & 109.67 & 401.67 & 410.00 & 25.30 & 25.06 & 4.45 & 4.50 \\
\hline & 60 & 96.67 & 96.67 & 372.33 & 371.67 & 24.50 & 24.36 & 4.01 & 4.26 \\
\hline \multirow{4}{*}{50} & Control & 74.33 & 71.33 & 351.33 & 348.00 & 20.83 & 20.60 & 2.53 & 2.70 \\
\hline & 20 & 82.33 & 83.00 & 359.33 & 354.33 & 23.66 & 24.20 & 4.20 & 3.99 \\
\hline & 40 & 95.33 & 98.33 & 380.67 & 378.00 & 24.96 & 24.76 & 4.26 & 4.21 \\
\hline & 60 & 90.33 & 88.67 & 370.33 & 377.33 & 24.60 & 24.53 & 4.12 & 4.17 \\
\hline L.S.D 0.05 & & 4.68 & 3.75 & 6.46 & 8.18 & 0.58 & 0.48 & 0.20 & 0.19 \\
\hline
\end{tabular}

on grain yield, number of filled grains, numbers of panicles $/ \mathrm{m}^{2}$ and 1000 -grain weight in the two growing seasons. It was clear that the interaction between $40 \mathrm{~kg}$ seeds/fed seeding rate under $40 \mathrm{Kg} \mathrm{N} / \mathrm{fed}$ gave the highest value of grain yield (4.45 and $4.50 \mathrm{t} / \mathrm{fed})$, number of filled grains/panicle (114.67 and 109.67), numbers of panicles $/ \mathrm{m}^{2}$ (401.67 and 410.00) and 1000grain weight (25.30 and $25.06 \mathrm{~g}$ ) in 2014 and 2015 seasons, respectively. These results are in harmony with those obtained by Abdel-Hamed (2005) and Salem et al. (2011).

Table (4) indicated that no significant difference was observed in traits hulling $\%$, milling $\%$ and broken rice $\%$ traits at different seeding rates in both seasons. On the other hand, nitrogen application scheduling had significant effect on these traits. The highest hulling \% values (79.51and $79.60 \%$ ) resulted from $40 \mathrm{Kg} \mathrm{N} / \mathrm{fed}$ application in 2014 and 2015 respectively, however, the lowest values (78.65 and $78.59 \%$ ) resulted from the control treatment in 2014 and 2015 seasons, respectively. Where, the highest milling $\%$ values (70.55and $70.50 \%$ ) resulted from $40 \mathrm{Kg} \mathrm{N} / \mathrm{fed}$ application in 2014 and 2015 respectively, however, the lowest values $(69.77$ and $69.56 \%$ ) resulted from the control treatment in 2014 and 2015 seasons, respectively. Hulling\%, milling \% were increased with increasing nitrogen levels and the best results were recorded with $40 \mathrm{Kg}$ N/fed application. 
Table 4. Hulling\%, milling\%and broken rice\% of Giza 179 rice cultivar as affected by seeding nitrogen levels during 2014 and 2015 seasons

\begin{tabular}{|c|c|c|c|c|c|c|}
\hline \multirow{2}{*}{ Main effects \& interaction } & \multicolumn{2}{|c|}{ Hulling \% } & \multicolumn{2}{|c|}{ Milling \% } & \multicolumn{2}{|c|}{ Broken rice \% } \\
\hline & 2014 & 2015 & 2014 & 2015 & 2014 & 2015 \\
\hline \multicolumn{7}{|l|}{ Seeding rate $(\mathrm{S})$ : } \\
\hline $20 \mathrm{Kg} / \mathrm{fed}$ & 78.94 & 78.95 & 70.05 & 69.95 & 12.57 & 11.62 \\
\hline $30 \mathrm{Kg} / \mathrm{fed}$ & 79.01 & 79.03 & 70.16 & 69.96 & 12.14 & 11.42 \\
\hline $40 \mathrm{Kg} / \mathrm{fed}$ & 79.25 & 79.21 & 70.30 & 70.11 & 11.96 & 10.95 \\
\hline $50 \mathrm{Kg} / \mathrm{fed}$ & 79.16 & 79.01 & 70.22 & 70.21 & 11.98 & 11.21 \\
\hline L.S.D $D_{0.05}$ & n.s & n.s & n.s & n.s & n.s & n.s \\
\hline \multicolumn{7}{|c|}{ Nitrogen levels $(\mathrm{N})$ : } \\
\hline Control & 78.65 & 78.59 & 69.77 & 69.56 & 12.55 & 11.95 \\
\hline $20 \mathrm{Kg} \mathrm{N} / \mathrm{fed}$ & 78.77 & 78.52 & 69.94 & 69.82 & 12.04 & 11.54 \\
\hline $40 \mathrm{Kg} \mathrm{N} / \mathrm{fed}$ & 79.51 & 79.60 & 70.55 & 70.50 & 12.10 & 11.43 \\
\hline $60 \mathrm{Kg} \mathrm{N} / \mathrm{fed}$ & 79.41 & 79.49 & 70.46 & 70.36 & 11.94 & 11.27 \\
\hline L.S.D $D_{0.05}$ & 0.22 & 0.25 & 0.24 & 0.23 & 0.11 & 0.18 \\
\hline \multicolumn{5}{|c|}{ Interaction: } & n.s & $\mathrm{n} \cdot \mathrm{s}$ \\
\hline
\end{tabular}

The brews data are in a good harmony with those reported by Singh et al. (2015).Broken rice \% decreased with increasing nitrogen levels,

however, the highest broken rice \% values (12.55 and $11.95 \%)$ resulted from the control treatment in 2014 and 2015 respectively, however, the lowest values (11.94 and $11.27 \%$ ) resulted from $60 \mathrm{Kg} \mathrm{N} / \mathrm{fed}$ application in 2014 and 2015 seasons, respectively.

Data in table (5), showed the effect of both seeding rates and nitrogen levels on physical properties of the grains during 2014 and 2015 seasons. Grain length was significantly affected with different seeding rates. The highest grain length values (5.43 and $5.33 \mathrm{~mm}$ ) resulted from $40 \mathrm{Kg}$ seeds/fed in 2014 and 2015 reasons respectively, however, the lowest grain length values $(5.30$ and $5.20 \mathrm{~mm})$ resulted from $20 \mathrm{Kg}$ seeds/fed in 2014 and 2015 reasons respectively. The grain width (mm) was insignificantly affected with different seeding rates in both seasons. Significant difference was conducted at grain thickness (mm) in 2014 and 2015 seasons, respectively. The highest grain thickness values (1.94 and $1.91 \mathrm{~mm}$ ) resulted from $40 \mathrm{Kg}$ seeds/fed in 2014 and 2015 reasons respectively, however, the lowest grain length values (1.89 and 1.86 $\mathrm{mm}$ ) resulted from $20 \mathrm{Kg}$ seeds/fed in 2014 and 2015 reasons respectively. The grain shape (L/W ratio) was insignificantly affected with different seeding rates in both seasons.

However, application of various nitrogen levels significantly affected grain length in both seasons. However, increasing levels of nitrogen increased grain length over the control. The maximum grain length value $(5.44$ and $5.35 \mathrm{~mm})$ resulted from $60 \mathrm{Kg} \mathrm{N} / \mathrm{fed}$ application in 2014 and 2015 seasons, respectively. There were significant differences in grain width among nitrogen rates during two seasons, maximum grain width ( 2.55 and $2.52 \mathrm{~mm}$ ) were recorded with the application of 40 and $60 \mathrm{~kg} \mathrm{~N} / \mathrm{fed}$ in 2014 and 2015 seasons, respectively. The grain thickness recorded maximum values (1.95 and $1.93 \mathrm{~mm})$ with the application of $60 \mathrm{~kg} \mathrm{~N} / \mathrm{fed}$ in 2014 and 2015 seasons, respectively. Grain length width ratio was not significantly affected by nitrogen levels in both study seasons. These results are in line with those of Maqsood et,al. (2013). The interaction between the different seeding rates and nitrogen levels application was not significant.

Means of protein content, gel consistency and gelatinization temperature during 2014 and 2015 seasons are presented in table (6). Protein content was affected by different seeding rates, where, the highest values (8.64 and $8.66 \%$ ) resulted from sowing $40 \mathrm{Kg}$ seeds/fed in 2014 and 2015 respectively, however, the lowest values ( 8.36 and $8.35 \%$ ) resulted from $20 \mathrm{Kg}$ seeds/fed in 2014 and 2015seasons, respectively. Also, protein content was significantly affected by different nitrogen levels. The highest values (8.59 and $8.60 \%$ ) resulted from $40 \mathrm{Kg}$ N/fed application in 2014 and 2015 seasons, respectively. However, the lowest values (8.45 and $8.32 \%$ ) resulted from control treatment in 2014 and 2015 seasons, respectively. These results are in harmony with those reported by Ahmed et al. (2009).

Seeding rates did not affect the gel consistency in the 2014 season. However, there were significant difference in gel consistency among seeding rates during 2015 season, the highest value $88.67 \mathrm{~mm}$ resulted from $50 \mathrm{Kg}$ Seeds/fed, however, the lowest value $87.17 \mathrm{~mm}$ resulting from $20 \mathrm{Kg}$ Seeds/fed in 2015 season. Data in table (6) showed that gel consistency was significantly affected by different nitrogen levels. 
Table 5. Grain length, width, thickness and shape of Giza 179 rice cultivar as affected by seeding rates and nitrogen levels during 2014 and 2015 seasons

\begin{tabular}{|c|c|c|c|c|c|c|c|c|}
\hline \multirow{2}{*}{$\begin{array}{c}\text { Main effects \& } \\
\text { interaction }\end{array}$} & \multicolumn{2}{|c|}{ Grain length (mm) } & \multicolumn{2}{|c|}{$\begin{array}{c}\text { Grain width } \\
\text { (mm) }\end{array}$} & \multicolumn{2}{|c|}{$\begin{array}{c}\text { Grain thickness } \\
\text { (mm) }\end{array}$} & \multicolumn{2}{|c|}{$\begin{array}{c}\text { Grain shape } \\
\text { (L/w ratio) }\end{array}$} \\
\hline & 2014 & 2015 & 2014 & 2015 & 2014 & 2015 & 2014 & 2015 \\
\hline \multicolumn{9}{|l|}{ Seeding rate $(\mathrm{S})$ : } \\
\hline $20 \mathrm{Kg} / \mathrm{fed}$ & 5.30 & 5.20 & 2.49 & 2.44 & 1.89 & 1.86 & 2.13 & 2.16 \\
\hline $30 \mathrm{Kg} / \mathrm{fed}$ & 5.38 & 5.28 & 2.54 & 2.47 & 1.90 & 1.88 & 2.12 & 2.14 \\
\hline $40 \mathrm{Kg} / \mathrm{fed}$ & 5.43 & 5.33 & 2.47 & 2.43 & 1.94 & 1.91 & 2.16 & 2.16 \\
\hline $50 \mathrm{Kg} / \mathrm{fed}$ & 5.32 & 5.25 & 2.49 & 2.46 & 1.93 & 1.90 & 2.13 & 2.14 \\
\hline L.S.D $D_{0.05}$ & 0.02 & 0.03 & n.s & n.s & 0.02 & 0.02 & n.s & n.s \\
\hline \multicolumn{9}{|l|}{ Nitrogen levels $(\mathrm{N})$ : } \\
\hline Control & 5.27 & 5.24 & 2.46 & 2.40 & 1.87 & 1.85 & 2.14 & 2.15 \\
\hline $20 \mathrm{Kg} \mathrm{N} / \mathrm{fed}$ & 5.31 & 5.29 & 2.48 & 2.44 & 1.89 & 1.87 & 2.14 & 2.14 \\
\hline $40 \mathrm{Kg} \mathrm{N} /$ fed & 5.35 & 5.30 & 2.55 & 2.49 & 1.94 & 1.91 & 2.13 & 2.15 \\
\hline $60 \mathrm{Kg} \mathrm{N} / \mathrm{fed}$ & 5.44 & 5.35 & 2.51 & 2.52 & 1.95 & 1.93 & 2.14 & 2.16 \\
\hline L.S.D 0.05 & 0.06 & 0.03 & 0.03 & 0.01 & 0.01 & 0.02 & n.s & n.s \\
\hline \multicolumn{9}{|l|}{ Interaction: } \\
\hline $\mathrm{S} \times \mathrm{N}$ & n.s & n.s & n.s & n.s & n.s & n.s & n.s & n.s \\
\hline
\end{tabular}

Table 6. Protein content, Gel Consistency and Gelatinization Temperature of Giza 179 rice cultivar as affected by seeding rates and nitrogen levels during 2014 and 2015 seasons

\begin{tabular}{|c|c|c|c|c|c|c|c|c|}
\hline \multirow{2}{*}{ Main effects \& interaction } & \multicolumn{2}{|c|}{ Protein \% } & \multicolumn{2}{|l|}{ G.C } & \multicolumn{2}{|c|}{ G.T (spreading) } & \multicolumn{2}{|c|}{ G.T (clearing) } \\
\hline & 2014 & 2015 & 2014 & 2015 & 2014 & 2015 & 2014 & 2015 \\
\hline \multicolumn{9}{|l|}{ Seeding rate $(\mathrm{S})$ : } \\
\hline $20 \mathrm{Kg} / \mathrm{fed}$ & 8.36 & 8.35 & 90.25 & 87.17 & 5.09 & 4.86 & 4.22 & 4.14 \\
\hline $30 \mathrm{Kg} / \mathrm{fed}$ & 8.54 & 8.50 & 90.33 & 87.66 & 5.15 & 4.96 & 4.34 & 4.23 \\
\hline $40 \mathrm{Kg} / \mathrm{fed}$ & 8.64 & 8.66 & 91.17 & 88.25 & 5.31 & 5.13 & 4.45 & 4.32 \\
\hline $50 \mathrm{Kg} / \mathrm{fed}$ & 8.49 & 8.52 & 90.75 & 88.67 & 5.27 & 5.06 & 4.36 & 4.24 \\
\hline L.S.D ${ }_{0.05}$ & 0.03 & 0.12 & n.s & 0.96 & 0.16 & 0.11 & n.s & 0.11 \\
\hline \multicolumn{9}{|l|}{ Nitrogen levels $(\mathrm{N})$ : } \\
\hline Control & 8.45 & 8.32 & 88.33 & 84.75 & 4.90 & 4.68 & 4.18 & 4.09 \\
\hline $20 \mathrm{Kg} \mathrm{N} / \mathrm{fed}$ & 8.51 & 8.47 & 90.17 & 88.42 & 5.15 & 4.93 & 4.30 & 4.17 \\
\hline $40 \mathrm{Kg} \mathrm{N} / \mathrm{fed}$ & 8.59 & 8.60 & 92.67 & 89.50 & 5.47 & 5.32 & 4.46 & 4.34 \\
\hline $60 \mathrm{Kg} \mathrm{N} / \mathrm{fed}$ & 8.50 & 8.57 & 91.33 & 89.08 & 5.30 & 5.09 & 4.44 & 4.32 \\
\hline L.S.D 0.05 & 0.04 & 0.03 & 1.19 & 1.24 & 0.20 & 0.14 & 0.10 & 0.10 \\
\hline \multicolumn{9}{|l|}{ Interaction: } \\
\hline $\mathrm{S} \times \mathrm{N}$ & n.s & n.s & n.s & n.s & n.s & n.s & n.s & n.s \\
\hline
\end{tabular}

The highest values $(92.67-89.50 \mathrm{~mm})$ resulted from $40 \mathrm{Kg} \mathrm{N} /$ fed application in 2014 and 2015 seasons,

however, the lowest values $(88.33,-84.75 \mathrm{~mm}$ ) resulted from control treatment in 2014 and 2015 seasons respectively. These results are in line with those obtained with Abdel-Salam et, al. (2014).

Gelatinization temperature (spreading and clearing) determines water absorption and the time required for cooking. It may also reflect the hardness of rice starch granules for cooking, Badawi (2002).However, spreading was affected by different seeding rates, where, the highest values (5.31 and 5.13) resulted from sowing $40 \mathrm{Kg}$ seeds/fed in 2014 and 2015 respectively, however, the lowest values ( 5.9 and 4.86) resulted from $20 \mathrm{Kg}$ seeds/fed in 2014 and 2015 seasons, respectively.

Also, spreading was significantly affected by different nitrogen levels. The highest values (5.47 and 5.32) resulted from $40 \mathrm{Kg} \mathrm{N} /$ fed application in 2014 and 2015seasons, respectively. However, the lowest values (4.90 and 4.68) resulted from control treatment in 2014 and 2015 seasons, respectively. These results are agreement with those reported by Pang (2016).

Clearing was not affected by different seeding rates in 2014 season, but was affected by different seeding rates, where, the highest values 4.32 resulted from 
Table 7. Hardness, Elongation and amylose content of Giza 179 rice cultivar as affected by seeding rates and nitrogen levels during 2014 and 2015 seasons

\begin{tabular}{|c|c|c|c|c|c|c|}
\hline \multirow{2}{*}{ Main effects \& interaction } & \multicolumn{2}{|c|}{ Hardness } & \multicolumn{2}{|c|}{ Elongation } & \multicolumn{2}{|c|}{ Amylose } \\
\hline & 2014 & 2015 & 2014 & 2015 & 2014 & 2015 \\
\hline \multicolumn{7}{|l|}{ Seeding rate $(\mathrm{S})$ : } \\
\hline $20 \mathrm{Kg} / \mathrm{fed}$ & 5.20 & 5.06 & 53.50 & 51.50 & 18.85 & 18.68 \\
\hline $30 \mathrm{Kg} / \mathrm{fed}$ & 5.25 & 4.90 & 54.06 & 51.25 & 18.90 & 18.78 \\
\hline $40 \mathrm{Kg} / \mathrm{fed}$ & 5.55 & 5.16 & 55.92 & 53.58 & 19.10 & 18.90 \\
\hline $50 \mathrm{Kg} / \mathrm{fed}$ & 5.53 & 5.15 & 55.25 & 52.25 & 19.06 & 18.85 \\
\hline L.S.D ${ }_{0.05}$ & n.s. & n.s. & 1.45 & 1.68 & 0.12 & 0.09 \\
\hline \multicolumn{7}{|l|}{ Nitrogen levels $(\mathrm{N})$ : } \\
\hline Control & 4.60 & 4.33 & 54.17 & 51.33 & 18.67 & 18.39 \\
\hline $20 \mathrm{Kg} \mathrm{N} / \mathrm{fed}$ & 5.18 & 4.75 & 54.25 & 51.58 & 18.86 & 18.68 \\
\hline $40 \mathrm{Kg} \mathrm{N} / \mathrm{fed}$ & 5.83 & 5.50 & 55.25 & 53.92 & 19.30 & 19.17 \\
\hline $60 \mathrm{Kg} \mathrm{N} / \mathrm{fed}$ & 5.96 & 5.60 & 55.08 & 51.75 & 19.10 & 18.96 \\
\hline L.S.D $D_{0.05}$ & n.s. & 0.16 & n.s. & 1.23 & 0.17 & 0.16 \\
\hline \multicolumn{7}{|l|}{ Interaction: } \\
\hline $\mathrm{S} \times \mathrm{N}$ & n.s. & n.s. & n.s. & n.s. & n.s. & n.s. \\
\hline
\end{tabular}

sowing $40 \mathrm{Kg}$ seeds/fed in 2015 , however, the lowest value 4.14 resulted from $20 \mathrm{Kg}$ seeds/fed in2015season. However, clearing was significantly affected by different nitrogen levels. The highest values (4.46 and 4.34) resulted from $40 \mathrm{Kg} \mathrm{N} /$ fed application in 2014 and 2015seasons, respectively. However, the lowest values (4.18 and 4.09) resulted from control treatment in 2014 and 2015 seasons, respectively. Similar results were reported by Kong (2015). There was no interaction between the different seeding rates and nitrogen levels application.These results are harmony with reported by Abdel-Salm et, al. (2014).

Hardness, elongation and amylose content results are presented in Table (7). Regarding nitrogen levels effect, the highest values of hardness were 5.96 with 60 $\mathrm{Kg} \mathrm{N} / \mathrm{fed}$ in 2014 season and 5.60 with $60 \mathrm{Kg} \mathrm{N} / \mathrm{fed}$ in 2014 season and 5.60 with $60 \mathrm{Kg} \mathrm{N} /$ fed in 2015 season, however, the lowest values recorded 4.60, 4.33 resulted from the control treatment in 2014 and 2015 seasons, respectively.

Concerning grain elongation, the highest values were $55.92,53.58$ with $40 \mathrm{Kg}$ seeds/fed in 2014 and 2015 seasons, while the lowest values recorded 53.50, 51.25 with 20 and $30 \mathrm{Kg}$ seeds/fed in both seasons, respectively. As for nitrogen levels affect the highest values of elongation $55.25,53.92$ with $40 \mathrm{Kg} \mathrm{N} /$ fed for both seasons, however, the lowest values 54.17, 51.33 recorded with control treatment in 2014 and 2015 seasons respectively.

Amylose content had values 19.10 and 18.90 with $40 \mathrm{Kg}$ seeds/fed in 2014 and 2015 seasons. Conversely, the lowest values obtained were 18.85 and 18.68 with 20 $\mathrm{Kg}$ seeds/fed in both seasons, respectively. Nitrogen levels affected amylose content, where the highest values 19.30 and 19.17 resulted from $40 \mathrm{Kg} \mathrm{N} /$ fed in both seasons. However, the lowest values 18.67 and 18.39 resulted from control treatment in both seasons. These results were harmony with Ahmed et al. (2009).

It may be concluded that the application of nitrogen fertilizer offers a large scope for obtaining higher yield of rice and better grain quality. It appears that good results can be achieved by the seeding rate of $40 \mathrm{Kg}$ seeds fed ${ }^{1}$ combined with nitrogen application of $40 \mathrm{~kg}$ $\mathrm{N} \mathrm{fed}{ }^{-1}$.

\section{REFERENCES}

Abdel-Fattah, A. G. , M. M. El-Habashy ,W. M. El Khoby and M. M. Shehab .2013. Adjusting doses and splitting of nitrogen fertilization for Egyptian hybrid 1 rice variety under broadcasting seeded rice for optimum yield. J. Plant Production, Mansoura Univ. 4 (2): 287 - 312.

Abdel-Hamed, N.N.B. 2005. Studies on the effect of some agronomic practices on characters and grain quality of rice. M. Sc. Thesis, Agron. Dept. of Agric., Kafr ElSheikh, Tanta Univ., Egypt.

Abdel-Salam, K.M.H., A. M. Shaalan and M.A.E. El-Dalil. 2014. Effect of nitrogen fertilizer sources on grain yield, yield Components and grain quality of rice. Alex. Sci. Ex. J. 35(4):304-313.

Abou Khalifa, A.A., I.O. El-Rewainy, A.E. Abdel-Wahab, A.K.M. Salem. 2005. Effect of seedling rates and nitrogen levels on phenology, growth and yield of Sakha 101 and Sakha 102 rice cultivars under broadcast-seeded rate. Egypt. J. Agric. Res. 83(5B):435-445.

Ahmed, S., M. Zia-Ul-Haq, H. Ali, A. Ahmed, M.A. Khan, T. Khaliq, Z. Husnain, A.Hussain and G. Hoogenboom. 2009. Morphological and quality parameters of ORYZA SATIVA L. as affected by population dynamics, nitrogen fertilization and irrigation regimes. Pak. J. Bot. 41(3): 1259-1269. 
Alam, M., M. Islam and M. Islam, 2011. Farmers efficiency enhancement through input management: the issue of USG application in modern rice. Bangladesh J Agric Res. 36: $129-141$.

Ali, A. A.bou Khalifa, W. ELkhoby and E. M. Okasha. 2014. Effect of sowing dates and seed rates on some rice cultivars. Afri. J. Agri. Res. 9 (2): 196-201.

Ananthi, T., M. Amanullah and K. Subramanian. 2010. Influence of mycorrhizal and synthetic fertilizers on soil nutrient status and uptake in hybrid maize. Madras Agric. J. 97: 374-378.

Anis, A. EL Sabagh, A. Ghareb and I. EL-Rewainy.2016. Evaluation of promising lines in rice (Oryza sativa L.) to agronomic and genetic performance under Egyptian conditions. Int.J. Agron. and Agri. Res.(IJAAR) 8 (3): 52-57.

Awan, T. H., R. I. Ali, Z. Manzoor, M. Ahmad and M. Akhtar. 2011. Effect of different nitrogen levels and row spacing on the performance of newly evolved medium grain rice variety, KSK 133. The Journal of Animal \& Plant Sciences. 21(2): 231-234.

Badr, S.E., H. A. EL-Gindy, B. Hemidaand, A. M. El Lithy. 2007. Planting and harvesting method effects on rice productivity. Misr J. Ag. Eng. 24(2): 318-326.

Badawi, S.A.T., 2002. Physiological studies on rice crop. MSC. Thesis, Fac. Of Agric. Kafr El-Sheikh, Tanta Univ., Egypt.

Balasubramanian, V. and J.E. Hill. 2002. Direct seeding of rice in Asia: emerging issues and strategic research needs for the 21 st century. In: Pandey S, Mortimer M, Wade L, Tuong TP, Lopez K, Hardy B (eds), Direct Seeding: Research Strategies and Opportunities. Inter. Rice Res. Inst. Los Baňos, Philippines, pp. 15-42.

Bhowmick, N. and R. L. Nayak. 2000. Response of hybrid rice (Oryza saliva) varieties 'to nitrogen, phosphorus and potassium fertilizers during dry (boro) season in West Bengal. Indian J. Agron. 45(2):323-326.

Bilbao, M., J. Martinez and A. Delgado. 2004. Evaluation of soil nitrate as a predictor of nitrogen requirement for sugar beet grown in a Mediterranean climate. Agron. J. 96: 1825.

Black, C.A., D.D. Evans, L.E. Ensminger, J.L. White, F.E. Clark and R.C. Dinauer. 1965. Methods of soil analysis. Part 2: Chemical and Microbiological Properties. Agron. 9: 771-1572.

Bufogle, A., P. K. Bollich, R. J. Norman, J. L. Kovar, C.W. Lindau and R. E. Macchiavelli. (1997). Rice plant growthand nitrogen accumulation in drill-seeded and waterseeded culture. Soil Sci. Soc. Am. J. 61:832-839.

Dawe, D. 2005. Increasing water productivity in rice-based systems in Asia: Past trends, current problems, and future prospects. Plant Prod. Sci. 8: 221-230.

Depar,N.,I. Rajpar,M.Y. Memon,M. Imtiaz and Zia-ulHassan. 2011. Mineral nutrient densities in some domestic and exotic rice genotypes. Pak. J. Agri. Agril.Eng. vet. Sci. 27: $134-142$.
El-Kassaby, A. T., M. H. Ghonima, A. A. Abd-Allah and T. M. El-Hefnawy. 2012. Effect of seedling age and plant spacing on growth characters and yield of some rice cultivars. J. of Plant Production, Mansoura Univ. 3(4): 705-714.

El-Khoby, W.M. 2004. Study the effect of some cultural practices on rice crop. Ph. D. thesis, Fac. Agric. Kafr Elsheikh, Tanta. Univ.

Farooq, M., S.M.A. Basra and N. Ahmed. 2007. Improving the performance of transplanted rice by seed priming. Plant Growth Regul. 51: 129-137.

Gomez, K.A. and A.A. Gomez. 1984. Statistical Procedures for Agricultural Research. $2^{\text {nd }}$ Edition, John Wiley and Sons,N.Y.,U.S.A.

Gorgy, R.N. 2007. Effect of balanced fertilizers on productivity of hybrid and inbred rice varieties .J. Agric. Res. Kafr El-Sheikh Univ. 33 (1): 101-122.

Hassan A. and B. Kaviani. 2011. Assessment of direct seeded and transplanting methods of rice cultivars in the northern part of Iran. Afri. J. Agri. Res. 6 (31):6492-6498.

International Rice research Institute (IRRI). 1996. Standard Evaluation System for Rice. IRRI, Manila, Philippines. P52

Jehangir, W.A., I. Masih, S. Ahmed, M.A. Gill, M. Ahmad, R.A. Mann, M.R. Chaudhary and H. Turral. 2005. Sustaining crop water productivity in rice-wheat systems of South Asia: a case study from Punjab Pakistan. In: Draft Working Paper. Inter. Water Management, Ins. Lahore, Pakistan.

Maqsood, M., M. A. Shehzad, S.N. Azam and M. Iqbal. 2013. Rice cultures and nitrogen rate effects on yield and quality of rice (Oryza sativa L.). Tur. J. Agri. 37: 665-673.

Namba, T. 2005. A method of nitrogen application for maximizing rice yield in the Nile delta. Japanese J. Crop Sci. 74(3):253-259.

Nawaz, H. M. A. 2002. Effect of various levels and methods of nitrogen application on nitrogen use efficiency in rice Super Basmati. M.Sc. Thesis, Agron, Dept. Univ. Agric., Faisalabad.

Nguyen, N.V. and A. Ferrero. 2006. Meeting the challenges of global rice production. Paddy Water Environ. 4: 1-9.

Norman, R. J., D. Guindo, B. R. Wells and C. E. Wilson. 1992. Seasonal accumulation and partitioning of nitrogen15 in rice. Soil Sci. Soc. Am. J.56:1521-1527.

Pandey, S., M. Mortimer, I. Wade, T.P. Tuong, K. Lopez and B. Hardy. 2002. Direct seeding: research strategies and opportunities. International Rice Research Institute, Los Banos, the Philippines. p. 383.

Pang, Y., J.Ali, X. Wang, N.J. Franje, J.E.Revilleza, J. Xu and Z. Li. 2016. Relationship of rice grain amylose, gelatinization temperature and pasting properties for breeding better eating and cooking quality of rice varieties. https://doi.org/10.1371/journal.pone.0168483

Rao, A.N., D.E. Johnson, B.Sivaprasad, J.K. Ladha and A.M. Mortimer. 2007. Weed management in direct-seeded rice. Adv. Agron. 93: 153-255. 
Salem,A.K.M., W.M. ElKhoby, A.B. Abou-Khalifa and M. Ceesay. 2011. Effect of nitrogen fertilizer and seedling age on inbred and hybrid rice varieties. AmericanEurasian J. Agric. and Environ. Sci. 11 (5): 640-646.

Samonte, S., L. Wilson, J. Medley, S. Pinson, A. Mcclung and J. Lales. 2006. Nitrogen utilization efficiency, relationships with grain yield, grain protein and yield related traits in rice. Agron. J. 98: 168-176.

Sharief, A.E., M.H. El-Hinidi, A.A. Abd El-Rahman and G.M. Abdo. 2000. Rice productivity as influenced by planting dates and seedling. Age J. Ages. J. Agric. Sci. Mansoura Univ. 3:1511-15

Singh, D. K., P. C. Pandey, Priyanker, A.Qureshi and Shilpi Gupta. 2015. Nitrogen management strategies for direct seeded aerobic rice (Oryza sativa L.) grown in mollisols of Uttarakhand (India). International Journal of Appl. and Pure Sci. and Agri. (IJAPSA). 01 (7): 2394-2532.

Sultan, M.S., A.T.El-Kassaby, M.M.El-Habashy and A. S. Taha. 2014. Effect of nitrogenous fertilizer rates on rice yield, yield components and insect infestation of some rice cultivars. J. Plant Production, Mansoura Univ. 5 (3): $457-$ 467.

Tuong, T.P., B.A.M.Bouman, and M.Mortimer. 2005. More rice, less water integrated approaches for increasing water productivity in irrigated rice-based systems in Asia. Plant Prod. Sci. 8: 231-241.

Yoshida, S. 1981. Fundamentals of Rice Crop Science. Los Ban os, Philippines. IRRI, pp: 269.

Yousef, T., Sahar, F. Allahyar and D. Jahanfar, 2012. Effect of split application of nitrogen fertilizer on growth and yield of hybrid rice (GRH1). Australian J. of Basic \& Applied Sci. 6 (2): 1-10.

Kong, X., P. Zhu, Z. Sui, J. Bao. 2015. Physicochemical properties of starches from diverse rice cultivars varying in apparent amylose content and gelatinization temperature combinations. Food Chem. (40)172:433

\section{الملخص العربي}

تأثثر معدلات التقاوي ومستويات التسميد التيتروجينى على محصول الحبوب و مكوناته و صفات الجودة

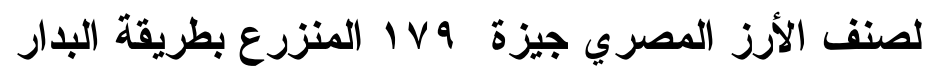
مدحت عبد المنعم الدليل، إيمان كمال الدين عبد الغنى، عزيز فؤاد ابو العز

أوضحت النتائج تأثر المحصول و مكوناته بكل من معدلات

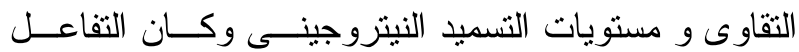
معنويا. بينما تأثرت صفات الجودة و هى الأميلوز ، محتوى البروتين، صفة استطالة الحبة، صفة صلابة الحبوب، صفة

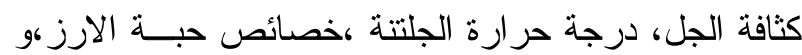

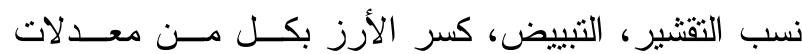

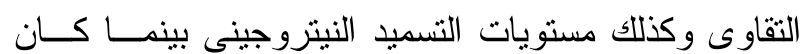
التفاعل بينهما غير معنويا لجميع هذه الصفات المدروســة.

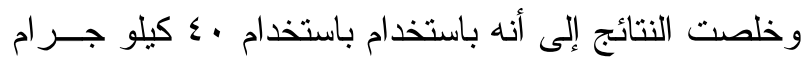

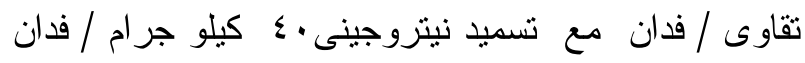

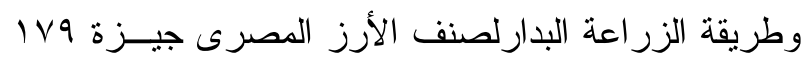

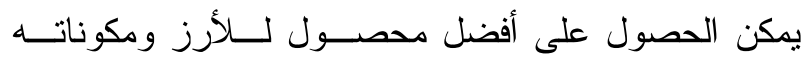
وكذلك صفات جودة جيدة للحبوب.
أجريت الدر اسة الحالية لمعرفة تأثيرمعـــلات التقــاوى

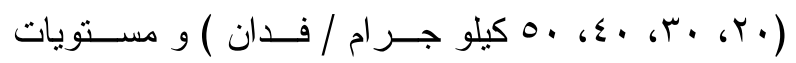

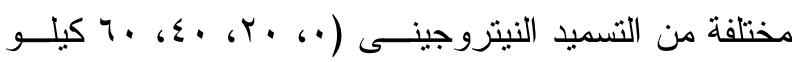
جرام / فدان ) على الصنف المصرى جيزة 1V9 المنزرع بطريقة البدار لتقييم محصول الحبوب ومكوناتــهـ وصـفات جودة الحبوب. تم إجر اء تجربتان حقليتان بمزرعة محطـــة البحوث الزر اعية بإيتاى البارود- محافظة البحيرة - مركز

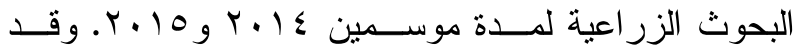
أظهرت النتائج أن معدل التقاوى (•ـ كيلو جرام / فــدان) أعطى معنوية عالية لصفة المحصول ( T.V. - T.VV)

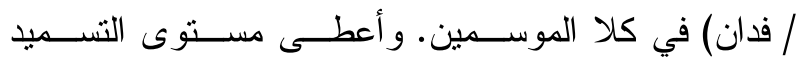

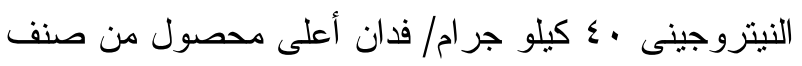

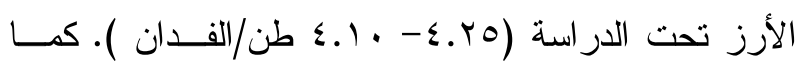

